Pregledni znanstveni rad DOI: $10.17234 /$ Croatica. 64.4

UDK: $811.163 .42 ’ 367.625$

Primljen: 10. V. 2019.

Prihvaćen: 20. IX. 2019.

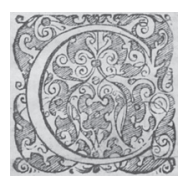

\title{
NEKOLIKO ZAPAŽANJA O HRVATSKIM RASPODJELNIM (ILI DISTRIBUTIVNIM) GLAGOLIMA
}

\author{
Mirko Peti \\ Institut za hrvatski jezik i jezikoslovlje, Zagreb \\ mirko.peti@zg.t-com.hr
}

U članku se sa sintaktičko-semantičkoga gledišta analizira posebna skupina hrvatskih glagola kojima je bitna značajka da im se pri upotrebi u rečenici glagolski sadržaj obavezno raspodjeljuje na više onih koji sudjeluju u njegovu ostvarivanju. Glagoli koji se ovdje razmatraju tek su malen dio golemog korpusa od oko 20-ak tisuća hrvatskih glagola raznih vrsta, računalno prikupljenih u Institutu za hrvatski jezik i jezikoslovlje za izradu Valencijskog rječnika hrvatskih glagola, kojemu sam bio voditeljem, i koji sam 2007. god. kao projekt (prihvaćen) prijavio Ministarstvu znanosti RH. Nakon kritičkog osvrta na opis distributivnih glagola u hrvatskoj gramatičkoj literaturi u članku slijedi njihovo razvrstavanje po semantičkim ulogama kako se one u tih glagola izriču imenskim riječima u funkciji subjekta i direktnoga objekta. Modelska podloga za to razvrstavanje bio mi je češki valencijski leksikon VALLEX 1.0 (Lopatkova i sur. 2003). Rečenične primjere za potrebe pokazivanja različitih tipova odnosa među distributivnim glagolima s obzirom na sudjelnike njihove radnje konstruirao sam po načelu ovjerenosti odnosno neovjerenosti rečenica u jeziku (hrvatskom) kojemu ti glagoli pripadaju.

Ključne riječi: raspodjelni (distributivni) glagoli, subjekt, objekt, sintaksa 


\section{ODREDBA RASPODJELNIH GLAGOLA}

Raspodjelni ili distributivni glagoli u hrvatskom su jeziku posebna i relativno malobrojna skupina perfektivnih glagola, tvorena od imperfektivnih prefiksima po-, iz-, poiz, raz-, koja se odlikuje specifičnim, značenjski određenim sintaktičkim svojstvom po kojemu im se glagolski sadržaj (radnja, zbivanje) pri upotrebi obavezno raspodjeljuje ili distribuira na više sudjelnika, ${ }^{1}$ na više onih koji kao istovrsni značenjski konstitutivni elementi sudjeluju u ostvarivanju radnje izrečene glagolom. Budući da distributivni glagoli mogu biti neprijelazni, povratni i prijelazni, u procesu raspodjeljivanja radnje na više sudjelnika ti sudjelnici glagolsku radnju mogu, načelno, ili vršiti ili trpiti, biti njezini ili vršitelji ili trpitelji. Tako se npr. radnja distributivnoga glagola poiskakati u rečenici tipa Putnici su poiskakali iz vlaka podjednako raspodjeljuje na više onih koji sudjeluju u vršenju radnje iskakanja, kao što se i radnja distributivnoga glagola poopijati se u rečenici tipa Mladići su se poopijali ravnomjerno raspodjeljuje na više onih koji sudjeluju u vršenju radnje opijanja. Jednako se tako i radnja distributivnoga glagola pozatvarati u rečenici tipa Pozatvarao je izgrednike podjednako raspodjeljuje na više onih koji trpe radnju zatvaranja. Niti radnje glagola poiskakati i poopijati se može vršiti jedan sudjelnik niti radnju glagola pozatvarati može trpiti jedan sudjelnik. Rečenice *Putnik je poiskakao iz vlaka ili *Mladić se poopijao ili *Pozatvarao je izgrednika u hrvatskom su jeziku neovjerene.

Da bi se sintaktički ostvarile, radnje se navedenih distributivnih glagola u sva tri slučaja moraju raspodijeliti na više sudjelnika. Upravo po tom svom semantičkom svojstvu ti glagoli i jesu raspodjelni ili distributivni. I upravo po tome se sa sintaktičko-semantičkoga gledišta razlikuju od glagola koji to nisu, kao što su npr. imperfektivni glagoli iskakati, opijati se i zatvarati, od kojih su prefiksacijom i nastali njihovi perfektivni distributivni parovi. Radnja je nedistributivnih glagola takva da se ne raspodjeljuje na sudjelnike,

\footnotetext{
Za pojam sudjelnik, a ne sudionik odlučio sam se zbog toga što se ovim prvim preciznije označuje ono o čemu je na semantičkoj razini u tih glagola riječ. A nije riječ o živoj osobi koja sudjeluje u ostvarivanju glagolske radnje, njezinu vršenju ili trpljenju, nego o specifičnom značenjski konstitutivnom elementu te radnje. Budući da pojam sudionik označuje osobu, i pretpostavlja samo živo, a značenjski se konstitutivni elementi radnje distributivnih glagola mogu obilježiti i kao semantički živi i kao semantički neživi, to je još jedan razlog više da se za imenovanje tih elemenata priklonimo upotrebi pojma sudjelnik. Tim se pojmom naime za elemente glagolske radnje na semantičkom planu, na kojemu i jesu definirani, podjednako pretpostavlja i oznaka živoga i oznaka neživoga.
} 
pa za njezino ostvarivanje nije potrebno više onih koji u njoj sudjeluju, nego je dovoljan i samo jedan sudjelnik, npr. Taj putnik je nekoliko puta iskakao iz vlaka, Mladić se danima opijao ili Tog su izgrednika zatvarali svaki mjesec. Svojstvo raspodjelnosti ili distributivnosti takvi glagoli ne dobivaju ni onda kad u ostvarivanju njihove radnje sudjeluje i više onih koji su u nju uključeni. U rečenicama tipa Putnici su iskakali iz vlaka, Mladići su se opijali ili Zatvarao je izgrednike radnja se imperfektivnih glagolā iskakati, opijati se i zatvarati ne raspodjeljuje na više sudjelnika unatoč činjenici da ima više onih koji je ostvaruju, dok je, nakon perfektivizacije glagola prefiksom po-, u slučaju s rečenicama tipa Putnici su poiskakali iz vlaka, Mladići su se poopijali i Pozatvarao je izgrednike, raspodjeljivanje radnje na više sudjelnika očito.

Razlika između distributivnih i nedistributivnih glagola, čak i onda kad u ostvarivanju radnje nedistributivnih sudjeluje više onih koji je ostvaruju, $\mathrm{u}$ tome je što u distributivnih glagola pri obaveznom raspodjeljivanju radnje na više sudjelnika tu radnju simultano ostvaruje svaki njezin sudjelnik pojedinačno, a u nedistributivnih glagola radnja se na više sudjelnika uopće ne raspodjeljuje, nego je oni koji su u nju uključeni ostvaruju kao količinski nedefinirana množinska cjelina. Prema tome, činjenica da formalno postoji više onih koji ostvaruju radnju određenoga glagola nipošto ne znači da je taj glagol nužno i distributivan. Upravo je obratno: tek distributivni glagol svojim specifičnim značenjskim obilježjem distributivnosti sintaktički određuje oblikovanje takve rečenične strukture kojom je jednoznačno zadano da se u ostvarivanju njegove radnje obavezno aktivira više sudjelnika matematički neodređenoga broja na koje se ta radnja podjednako raspodjeljuje. Smjer sintaktičke zavisnosti ide od konceptualno strukturiranoga značenja distributivnoga glagola prema sudjelnicima u njegovoj radnji, a ne obratno.

Ponegdje se u literaturi kao distributivni glagoli navode i glagoli koji u hrvatskom standardnom jeziku nisu distributivni, npr.: pobrisati (svu prašinu na polici), počistiti (sve sobe), pokositi (svu travu), pomaljati (sve zidove u kući), poštucati (sve voćke), povaljati (sve zarobljenike u blatu), povezati (sve niti u nekoj priči) (Dickey 2003: 108). Glagol nije distributivan ako mu se radnja ne raspodjeljuje na više sudjelnika, odnosno ako je za njezino vršenje dovoljan samo jedan sudjelnik, kao što je to slučaj za navedene glagole u ovim primjerima: pobrisati bilješku na margini teksta, počistiti mrlju na odijelu, pokositi djetelinu, pomaljati (obojiti) svaki zid drugom bojom, poštucati (zapravo podštucati) samo jabuku, povaljati pšenicu (vjetar) (a navedeno moguće distributivno značenje toga glagola u hrvatskom stan- 
dardnom jeziku ne postoji), povezati događaj s okolnostima itd. Navođenje kvantifikacijskih oznaka uz glagole (svu prašinu, sve sobe, svu travu, sve zidove, sve voćke, sve zarobljenike, sve niti) nije ni dovoljno ni presudno za kvalifikaciju tih glagola kao distributivnih. Glagoli koji nisu distributivni sami po sebi, distributivnost ne mogu dobiti po tim oznakama.

Raspodjelnost ili distributivnost, valja izričito naglasiti, semantičko je a ne gramatičko svojstvo distributivnih glagola. To je svojstvo za te glagole specifično i ograničeno na samo jednu i to brojem relativno ne osobito veliku glagolsku skupinu. Stoga to svojstvo pri upotrebi distributivnoga glagola kao predikata ne sudjeluje u oblikovanju gramatičkog ustrojstva rečenice, njegove čvrste, od glagolskoga značenja semantički neuvjetovane gramatičke strukture. Tim se svojstvom ni subjekt ni objekt u rečenici ne određuju kao gramatički definirane sintaktičke jedinice, niti činjenica raspodjeljivanja radnje distributivnoga glagola na više sudjelnika ima ikakav sintaktički relevantan odnos prema tim dvama dijelovima gramatičkoga rečeničnog ustrojstva. Time što se utvrđuje da je subjekt množinski, npr. putnici u rečenici Putnici su poiskakali iz vlaka, lingvistički je neopravdano tvrditi kako radnju glagola poiskakati vrši više subjekata. Jednako je tako lingvistički neopravdano tvrditi da se u rečenici Pozatvarao je izgrednike radnja glagola pozatvarati vrši na više objekata, samo zato što je nedvojbeno utvrdivo da je tu riječ o množinskom objektu na koji prelazi glagolska radnja.

\section{BRKANJE SUBJEKATA I OBJEKATA SA SUDJELNICIMA RADNJE}

Unatoč tome što distributivnost glagolske radnje pojedinoga glagola u rečenici nema sintaktički relevantan odnos sa subjektom i objektom kao dijelovima gramatički definiranoga rečeničnog ustrojstva, i ničim ih ne određuje, u hrvatskoj se gramatičkoj literaturi kontinuirano, od Maretića do danas, svojstvo raspodjelnosti radnje distributivnih glagola na više sudjelnika izravno dovodi u vezu sa subjektom i objektom. I to tako što se subjekti i objekti u rečenicama s distributivnim glagolima pojmovno izjednačuju sa sudjelnicima radnje distributivnih glagola, kojih je uvijek mnogo, nikada jedan, pa se u tom kontekstu izričito tvrdi kako je u takvim slučajevima zapravo riječ o više subjekata i više objekata uz koje je vezana distributivna radnja.

Tako se npr. u Maretića veli kako ti glagoli, složeni s prijedlogom po, imaju ,značenje, da radnju čine mnogi subjekti (ako je glagol neprelazan) 
ili da se ona čini na mnogijem objektima (ako je glagol prelazan)" (Maretić 1899: 385, t. 395 a), u Grubora pak da im se ,radnja ne izvršuje samo na jednom objektu ili na malo njih, već na mnogima, tj. da glag. radnja obuhvaća više objekata i da se vrši na svakome od njih ponaosob”, odnosno da ,subjekt radnje nije samo jedan ili malo njih nego ih je više, od kojih svaki posebice vrši čitavu radnju simultano sa svima drugim subjektima" (Grubor 1953: 238), u Babića ,da se radnja izvršila na mnogim objektima ili da su je izvršili mnogi subjekti" (Babić 1986: 485, t. 1882), u Hrvatskoj gramatici skupine autora da se radnja tih glagola „vrši na više objekata ili imaju više subjekata” (Barić i dr. 1995: 223, t. 603 b). Jedino u Silić-Pranjkovićevoj Gramatici o odnosu radnje distributivnih glagola prema njezinim sudjelnicima i njihovu imenovanju nema izričitog izjašnjavanja; ondje se samo tvrdi da su to ,glagoli kojima se izriče raspodjela radnje" (Silić - Pranjković 2005: 58, t. 11).

Osim što je u hrvatskoj filologiji od samoga početka točno uočena bitna narav radnje distributivnih glagola, a to je da je za njezino ostvarivanje nužno pretpostaviti više onih na koje se ona raspodjeljuje, dovođenje te radnje u izravnu vezu sa subjektom i objektom, nakon što su ti dijelovi rečenice u hrvatskom jezikoslovlju konačno definirani isključivo gramatički, u opisu tih glagola više nije prihvatljivo. Niti gramatički definirani subjekti vrše radnju distributivnih glagola, niti se ta radnja vrši na gramatički definiranim objektima, niti gramatički definiranih subjekata i objekata uz distributivne glagole ima više. Navedenom se opisu tih glagola u hrvatskoj gramatičkoj literaturi međutim ne treba previše čuditi. On je logična posljedica nedovoljno dosljednoga razlikovanja i uzajamnog zamjenjivanja gramatičkih i semantičkih odnosa i njihove uloge u oblikovanju sintaktičkog ustrojstva rečenice na različitim razinama organiziranja. ${ }^{2}$

Između sudjelnikā radnje distributivnih glagola i subjekata, uz neprelazne i povratne, odnosno objekata uz prijelazne glagole, znak je jednakosti

2 Do nesporazuma tu dolazi zbog različitog tumačenja pojmova subjekt i objekt. Oni koji tvrde da radnju distributivnih glagola vrši više subjekata odnosno da se ona vrši na više objekata pojam subjekt očito shvaćaju kao stvarnog ili makar samo zamišljenog pojedinca koji vrši radnju, a pojam objekt kao stvarni ili makar samo zamišljeni predmet na kojemu se radnja vrši. Oni pak koji tvrde da radnju distributivnih glagola ne vrše subjekti niti se ona vrši na objektima pojam subjekt shvaćaju kao imensku riječ u nominativu koja se u licu i broju slaže s predikatom, a pojam objekt kao imensku riječ u akuzativu koja je u rečenicu uvedena prijelaznošću (distributivnoga) glagola. Da bi se nesporazum izbjegao, potrebno je pojmove subjekt i objekt upotrebljavati samo u gramatičkom smislu, a za označivanje dionikā radnje distributivnih glagola pronaći pojmove primjerenije od subjekta i objekta (v. bilj. 1). 
povučen zbog toga što nije bilo dovoljno precizno razlučeno gramatičko ustrojstvo rečenice od semantičkoga. Reći da radnju distributivnih glagola čine mnogi subjekti ili da se ona čini na mnogim objektima netočno je iz dvaju razloga. Prvo, s obzirom na gramatički status subjekta i objekta, s jedne strane, i semantički status raspodjelne radnje distributivnih glagola, s druge strane, znanstveno je neprihvatljivo tvrditi da radnju distributivnih glagola čine ili vrše subjekti odnosno da se ona čini ili vrši na objektima. Drugo, po mogućnosti otvaranja mjesta u rečenici subjektu i objektu distributivni se glagol u ulozi predikatnoga glagola svojim gramatičkim svojstvima ne razlikuje od ostalih tzv. normalnih glagola, a to znači da se uz jedan distributivni predikatni glagol u rečenici najčešće pojavljuje i jedan subjekt odnosno jedan objekt, pa je tvrdnja da radnju distributivnoga glagola nužno vrši više subjekata odnosno da se ona nužno vrši na više objekata neutemeljena. Niti je u rečenici Putnici su poiskakali iz vlaka riječ o više subjekata niti u rečenici Pozatvarao je izgrednike o više objekata. U prvoj rečenici riječ je o jednom subjektu, u drugoj o jednom objektu, koji su zbog naravi distributivnih glagola nužno u pluralu, a u obje rečenice riječ je o više sudjelnika na koje se raspodjeljuje glagolska radnja.

$\mathrm{Na}$ zaključak o više subjekata i više objekata istraživače su značenja distributivnih glagola očito naveli množinski oblici imenica kojima se uz te glagole subjekti i objekti nužno izriču. Predmnijevalo se: ako su uz distributivne glagole imenice za izricanje subjekata i objekata obavezno u množini, a množinom se izriče da je riječ o više onih koji sudjeluju u ostvarivanju glagolske radnje, onda se, izjednačujući subjekte i objekte sa sudjelnicima u radnji, stalo govoriti i o više subjekata i više objekata. Međutim iz same činjenice da su imenice kojima se subjekti i objekti izriču u množini ne može se valjano zaključiti da je riječ o više subjekata odnosno objekata. Kad predikatni glagol kao subjektu i objektu u rečenici otvara mjesto imenicama u množinskom obliku, kao npr. Susjedi zatvaraju prozore, riječ je o samo jednom subjektu (susjedi) i samo jednom objektu (prozore).

Stoga zaključivanje s množinskih oblika imenica na pretpostavku o više subjekata i objekata uz distributivne glagole nije opravdano. Imenicama u množini uz distributivne glagole u funkciji subjekta i objekta ne izriče se mnogo subjekata i mnogo objekata, nego se njihovom množinom izriče mnogo sudjelnika u ostvarivanju glagolske radnje. Imenicama u množini u funkciji subjekta i objekta mjesto u rečenici distributivni glagol ne otvara kao predikatni glagol svojim gramatičkim oblikom, nego kao glagol sa semantičkim svojstvom distributivnosti koja pretpostavlja mnoštvo sudjelnika u radnji 
i za njihovo izricanje zahtijeva oblike imenica kojima se to mnoštvo može izreći. Množinski je oblik imenica za to najčešći: Susjedi navečer pozatvaraju prozore, a budući da je riječ o prijelaznom distributivnom glagolu, subjekt može biti izrečen i jedninskim oblikom imenice: Susjed navečer pozatvara prozore, a ako je riječ o povratnom distributivnom glagolu, subjekt mora biti izrečen imenicom u množini: Susjedi se navečer pozatvaraju u kuće. I dok je uz nedistributivni glagol zatvarati u rečenici jedninski oblik imenice za subjekt i objekt moguć, npr. Susjed zatvara prozor, dotle uz distributivni glagol pozatvarati u rečenici jedninski oblik imenice za objekt nije moguć ni kad je imenica za subjekt u množini (*Susjedi su pozatvarali prozor), ni kad je imenica za subjekt u jednini (*Susjed je pozatvarao prozor). Množina imenica za izricanje subjekta i objekta uz distributivne glagole uvjetovana je distributivnošću glagola, raspodjeljivanjem njegove radnje na više sudjelnika, ali se unatoč tome njome ne izriče mnogo subjekata i mnogo objekata, kao nešto što bi bilo odlučno za definiranje radnje distributivnih glagola, nego se izriče samo jedan subjekt i samo jedan objekt.

\section{MNOŽINSKI I JEDNINSKI OBLICI IMENICA UZ RASPODJELNE GLAGOLE}

Da je množina imenica slaba podloga za zaključivanje o višesubjektnosti i višeobjektnosti uz distributivne glagole, uvjerljivo pokazuju i primjeri u kojima se uz te glagole za izricanje subjekta i objekta ne rabe imenice $u$ množini, nego imenice u jednini. Uzimajući u obzir gramatičku kategoriju broja tih imenica, jedninu, tu se više ne može govoriti ni o više subjekata ni o više objekata, a ipak se i u takvim slučajevima radnja distributivnih glagola ravnomjerno raspodjeljuje na više onih koji u njoj sudjeluju. Riječ je o rečenicama tipa Narod je poiskakao iz vlaka, Družina se poopijala i Pozatvarao je telad. Subjekti narod i družina i objekt telad u tim su rečenicama uz distributivne glagole iskazani jedninskim imenicama, i u svakoj rečenici nedvojbeno je riječ o samo jednom subjektu i samo jednom objektu, ali se unatoč tome u sva tri slučaja radnja distributivnoga glagola raspodjeljuje na više sudjelnika. To da je riječ o više onih na koje se glagolska radnja raspodjeljuje izrečeno je zbirnim imenicama narod, družina i telad. Nedvosmisleno pokazati da je riječ o jednom subjektu i jednom objektu i o više sudjelnika na koje se radnja raspodjeljuje uz distributivne je glagole bilo moguće zbog toga što te imenice, kao zbirne, imaju gramatički oblik jednine, 
a semantički oblik množine. Njihovim se semantičkim oblikom množine, unatoč gramatički jedninskom obliku, izriče više onih koji sudjeluju u ostvarivanju radnje distributivnoga glagola, njihov matematički neodrediv broj. ${ }^{3} \mathrm{~S}$ jedninskim oblicima imenica koje nisu zbirne to nije moguće. Uz jedninske se oblike tih imenica distributivni glagoli ne mogu upotrijebiti, npr. *Čovjek je poiskakao iz vlaka, *Žena se poopijala, *Pozatvarao je tele. Za njihovu upotrebu nužni su njihovi množinski oblici: Putnici su poiskakali iz vlaka, Žene su se poopijale, Pozatvarao je izgrednike.

Iz tih se primjera nedvosmisleno razabire da u rečenicama s distributivnim glagolima subjekte i objekte valja dosljedno razlikovati od sudjelnikā njihove radnje, kako onda kad je to sasvim očito, kao u slučaju sa zbirnim imenicama, kad je subjekt odnosno objekt samo jedan a sudjelnikā više, tako i onda kad se čini da je nešto manje očito, kao u slučaju s množinskim oblicima nezbirnih imenica, premda je i tu situacija potpuno identična. I, što je još važnije, u opisu distributivnih glagola jedne nipošto ne valja izjednačivati s drugima, subjekte i objekte sa sudjelnicima. I jedni se i drugi doduše u rečenicama izriču istim imenicama, pa to dijelom i jest dovelo do zabune, ali je ipak riječ o dvama različitim i međusobno odvojenim skupovima sintaktičkih svojstava tih imenica: gramatičkim i semantičkim. To je tako zato što ta dva skupa sintaktičkih svojstava tih imenica razlučuje sam distributivni glagol dvjema svojim također odvojenim sintaktičkim ulogama: gramatičkom i semantičkom. Gramatička su svojstva tih imenica u rečenici uz distributivne glagole aktualizirana gramatičkim svojstvima distributivnoga glagola kao predikata, a semantička su njihova svojstva aktualizirana semantičkim svojstvom raspodjelnosti radnje samoga distributivnog glagola.

\footnotetext{
Iz toga se može zaključiti da distributivni glagol sa svojom semantikom raspodjelnosti radnje na više sudjelnika može poslužiti kao pouzdan test za identifikaciju zbirnih imenica i njihovo razlikovanje od nezbirnih, pogotovo ondje gdje se zbirne imenice od nezbirnih ne razlikuju po svojim očiglednim morfološkim karakteristikama. Tim je testom moguće utvrditi da čak, uvjetno rečeno, jedna te ista imenica može imati i zbirno i nezbirno značenje. Tako npr. imenica neprijatelj uz distributivni glagol razbježati se u rečenici Neprijatelj se razbježao ima zbirno značenje, jer pretpostavlja više sudjelnika u radnji, a u rečenici Moj neprijatelj bježi nezbirno, jer ne pretpostavlja više sudjelnika u radnji; imenica neprijatelj nije sama po sebi zbirna, zbirnom ju čini distributivni glagol. Imenica riba uz distributivni glagol pougibati u rečenici Sva je riba tog ljeta pougibala ima zbirno, a u rečenici Jutros je ulovio veliku ribu nezbirno značenje. Takvo bi načelno utvrđivanje kontekstom uvjetovanih semantičkih potencijala imenica u hrvatskom jeziku uvelike pripomoglo ne samo njihovu svrhovitijem gramatičkom razvrstavanju nego i boljem leksikografskom opisu.
} 
S jedne strane, distributivni glagol, poput svih ostalih glagola, svojim finitnim oblikom kao predikat otvara u rečenici mjesto subjektu odnosno svojim gramatičkim svojstvom prijelaznosti mjesto objektu, a tek, s druge strane, onim po čemu se bitno razlikuje od ostalih glagola, svojim semantičkim svojstvom distributivnosti, određuje kojim će imenicama i u kojem njihovu obliku taj subjekt i taj objekt biti izrečeni. Temeljni je uvjet uvijek isti: da to budu imenice odnosno njihovi oblici kojima se izriče više onih na koje će se moći raspodijeliti radnja distributivnoga glagola.

Jedninom imenica koje su s gledišta kategorije broja regularne, tj. imaju i jedninu i množinu, dakle nisu zbirne, tu potrebu izricanja većeg broja onih na koje bi se raspodjeljivala radnja distributivnoga glagola nije moguće zadovoljiti. Takvu je potrebu moguće zadovoljiti samo množinom tih imenica. Jedino se u tom obliku tim imenicama izriče da je onih koji sudjeluju u glagolskoj radnji više. Zbog toga je uz distributivni glagol u ulozi predikata za izricanje subjekta i objekta množina tih imenica obavezna, neizostavljiva. Njome se postiže to da se uz distributivni glagol u predikatu istom imenicom u množini istodobno izriče jedan subjekt odnosno jedan objekt i više sudjelnika na koje se raspodjeljuje glagolska radnja. Ondje gdje se veći broj onih koji sudjeluju u glagolskoj radnji može izreći imenicom u jednini, kao što je slučaj sa zbirnim imenicama, tipa narod, družina, telad, lišće itd., množinski oblik imenice uz distributivni glagol prestaje biti obavezan, a obaveznim postaje upravo njezin jedninski oblik. Neutemeljena je, prema tome, skrovita pretpostavka da su uz distributivne glagole za izricanje subjekta i predikata apsolutno obavezni samo množinski oblici imenica. Činjenica je da su i množinski i jedninski oblici imenica uz te glagole obavezni samo pod točno određenim uvjetima koje smo ovdje naveli.

$\mathrm{Na}$ temelju toga zaključno se dakle može reći da subjekti i objekti u rečenicama s distributivnim glagolima kao predikatima (u množini ili jednini), za potrebe izricanja većeg broja sudjelnika, mogu, alternativno, biti izrečeni ili imenicama u množini ili zbirnim imenicama (koje su gramatički jedninske a semantički množinske). Samo je tada zadovoljen temeljni uvjet funkcioniranja distributivnoga glagola, a to je da su stvorene nužne sintaktičke pretpostavke po kojima mu se radnja može raspodjeljivati na više onih koji sudjeluju u njezinu ostvarivanju. Na semantičkoj razini sudjelnici radnje distributivnih glagola izriču se, prema tome, istim onim imenicama, bilo u množini ili u jednini, kojima se na gramatičkoj razini izriču i subjekti odnosno objekti. 


\section{SEMANTIČKE ULOGE UZ RASPODJELNE GLAGOLE}

No osim sintaktičkih uloga izricanja subjekata i objekata s jedne strane i sudjelnikā glagolske radnje s druge strane te imenice imaju još jednu ulogu. To je uloga specificiranja sudjelnikā glagolske radnje s obzirom na njihov položaj u njoj kakav je zadan specifičnim konceptualnim značenjem pojedinoga glagola kojim mu je definiran njegov valencijski okvir. Osim što se radnja distributivnih glagola obavezno raspodjeljuje na više sudjelnika, u njezinu ostvarivanju ti sudjelnici participiraju na različite načine, sa svojim posebnim semantičkim ulogama, kao vršitelji, trpitelji, učinci itd. Budući da se sudjelnici izriču istim imenicama kojima se u rečenici izriču subjekti i objekti, za potpuniji opis semantičkog ustroja distributivnih glagola potrebno je pobliže razgledati kakve su sve specificirane semantičke uloge sudjelnikā glagolske radnje koji se izriču imenicama u ulozi subjekta i objekta.

Imenska riječ u funkciji subjekta uz distributivne glagole može imati različite semantičke uloge, ne samo jednu. Koja će se od ulogā aktualizirati, ovisi o tome koje posebno konceptualno značenje, osim temeljnoga distributivnoga, ima pojedini glagol. Po opisu distributivnih glagola u hrvatskoj gramatičkoj literaturi svaki je subjekt, izrečen imenskom riječju u nominativu - vršitelj radnje. I više od toga: samo vršitelj, i ništa drugo. Međutim primjeri distributivnih glagola pokazuju da nijedno od toga dvoga nije točno. Niti subjekt načelno valja izjednačiti s vršiteljem niti se uz distributivne glagole imenskom riječju u nominativu u ulozi subjekta izriče samo vršitelj njihove radnje. Suprotno očekivanju, po našem uvidu broj je distributivnih glagola s imenskom riječju u funkciji subjekta kojom se izriče i semantička uloga vršitelja radnje neznatan.

Kao imenska riječ u nominativu subjekt se može izreći uz distributivne glagole bez povratne zamjenice is povratnom zamjenicom se. Među nešto više od četrdeset distributivnih glagola bez povratne zamjenice se nalazi se tek šest njih uz koje se imenskom riječju u funkciji subjekta izriču i vršitelji njihove radnje. To su: poskakati, poiskakati, polijegati, posjedati, poustajati, poslijetati (mladići su poskakali, putnici su poiskakali, ukućani su polijegali, gosti su posjedali, učenici su poustajali, golubovi su poslijetali). Pritom valja primijetiti da se i uz neke od tih glagola s ponešto izmijenjenim značenjem, prema neživomu, mijenja i semantička uloga imenske riječi u funkciji subjekta, pa se njome više ne izriču vršitelji glagolske radnje, nego se, kao što primjeri pokazuju, izriču njezini učinci odnosno posljedci, npr. cijene su poskakale, opruge su poiskakale. Uza sve ostale distributivne glagole bez 
povratne zamjenice se $\mathrm{s}$ imenicom u nominativu u funkciji subjekta tom se imenicom ne izriču i vršitelji glagolske radnje, nego se izriču ili njezini trpitelji odnosno objekti obuhvaćeni radnjom ili zbivanjem, npr. poispadali su zubi, pokrepala je stoka, poumirali su starci, pocrkale su životinje, poozdravljali su bolesnici, poizgarale su kuće, pootpadalo je lišće, pougibali su štenci, popadale su jabuke, putnici su pozadrijemali, mladići su pozaspali, ili učinci odnosno posljedci radnje ili zbivanja, npr. biljke su ponicale, poiznicale su visibabe, poizbijale su mladice.

I među nešto više od šezdeset distributivnih glagola s povratnom zamjenicom se ima vrlo malo onih uz koje se imenskom riječju u nominativu u funkciji subjekta izriču vršitelji glagolske radnje na koje se ona raspodjeljuje. Takvi su: poispravljati se, poizdizati se, poizmicati se, pooblačiti se, poopijati se, porazići se, porazmaknuti se, porazmjestiti se, posakrivati se, raseliti se, razbježati se (vježbači su se poispravljali, gazde su se poizdizale, prosvjednici su se poizmicali, djevojke su se pooblačile, mladići su se poopijali, prijatelji su se porazišli, ljudi su se porazmaknuli, žene su se porazmjestile, djeca su se posakrivala, obitelji su se raselile, divljač se razbježala). Mnogo je više onih distributivnih glagola s povratnom česticom se uz koje se imenskom riječju u nominativu u funkciji subjekta ne izriču vršitelji glagolske radnje, nego se, upravo obratno od očekivanoga, izriču njezini trpitelji odnosno objekti obuhvaćeni glagolskom radnjom ili zbivanjem. Takvi su: pogušiti se, poispodizati se, ponasukati se, pootvarati se, porasipati se, porazbijati se, porazbolijevati se, porazudavati se, porazvaliti se, porušiti se, posmrzavati se, poubijati se, poudati se, poudavati se, pozačepiti se, poženiti se i dr. (životinje su se pogušile, poispodizale su se katnice, ponasukali su se brodovi, pootvarale su se latice, porasipalo se zrnje, porazbijale su se čaše, porazbolijevali su se učenici, porazudavale su se djevojke, porazvalile su se ograde, porušile su se kuće, posmrzavale su se ruže, poubijali su se kitovi, poudale su se kćeri, poudavale su se sestre, pozačepili su se odvodi, sinovi su se poženili).

Od distributivnih glagola najveći je broj onih, njih oko dvjesto pedeset, koji imaju gramatičko svojstvo prijelaznosti. To znači da im radnja prelazi na imensku riječ u akuzativu u funkciji direktnog objekta i raspodjeljuje se na više sudjelnika koji su izrečeni tom riječju. Objekt je, dakako, ili u množini (Pozatvarao je prozore) ili, kad je izrečen zbirnom imenicom, u jednini (Isporazdjeljivao je imetak). Za razliku od imenske riječi u nominativu u funkciji subjekta, kojom se uz značenjski različito konceptualizirane distributivne glagole izriču i različite semantičke uloge koje bitno defini- 
raju njihovu radnju, imenskom se riječju u akuzativu u funkciji direktnoga objekta izriče samo jedna semantička uloga, a to je uloga trpitelja glagolske radnje odnosno objekta koji je njome obuhvaćen. Radnja se distributivnih glagola koji su prijelazni raspodjeljuje samo na one sudjelnike koji su sa semantičkim statusom trpitelja izrečeni imenskom riječju u akuzativu kao direktnim objektom.

Njezino se raspodjeljivanje $u$ tih glagola ne odnosi na imensku riječ $u$ nominativu kojom se izriče subjekt niti se njime toj riječi postavlja ikakav uvjet glede gramatičke kategorije broja. Zbog toga riječ kojom se uz te glagole izriče subjekt, bez ikakva utjecaja na njihovo funkcioniranje, jednako može biti i u jednini i u množini: Inspektor je pobilježio podatke i Inspektori su pobilježili podatke. Osim subjekata, istim se imenskim riječima u nominativu uz te glagole izriču i vršitelji njihove radnje: inspektor, inspektori itd. No kako se radnja tih glagola s prelaženjem na objekt obavezno raspodjeljuje na sudjelnike koji u njoj posredstvom imenske riječi u akuzativu funkcioniraju kao trpitelji, njezino raspodjeljivanje na vršitelje potpuno izostaje. Zato i jest posve nebitno jesu li imenske riječi kojima se izriču vršitelji u jednini ili u množini. A pokazuje se i to da se svojstvo raspodjelnosti radnje distributivnih glagola vezuje uvijek samo uz jedan tip semantičke uloge koja sudjeluje u aktualiziranju te radnje. Unatoč tome što su u rečenicama tipa Popisivač je popamtio kućne brojeve i Popisivači su popamtili kućne brojeve uz distributivni glagol popamtiti osim trpitelja izrečeni i vršitelji njegove radnje, jedan i više, ti se vršitelji u tim rečenicama sintaktički ponašaju jednako kao da stoje uz glagol koji nije distributivan. Svojstvo se raspodjelnosti navedenoga glagola na njih ne odnosi.

Među distributivnim glagolima koji su prijelazni najčešći su oni u kojih je pri izricanju sudjelnikā njihove radnje kao trpitelja moguće aktualizirati semantičku opreku živo - neživo. Takvi su npr. pozatvarati (lopove, prozore), pobacati (mačiće, odjeću), pohvatati (kriminalce, konce), poizljubiti (djecu, kamenje), pokupovati (istomišljenike, dionice), ponamještati (rođake, stolove), pootimati (stoku, posjede), pootkrivati (jatake, skloništa), popamtiti (učenike, ulice), popeći (janjce, kolače), popisati (izletnike, imovinu), porazdavati (djecu, cipele), porazmjestiti (doušnike, klupe), posakrivati (žene, puške), potovariti (radnike, trupce), povješati (pobunjenike, odijela), pozaboravljati (prijatelje, obveze), pozatvarati (neprijatelje, dućane) itd. Manji je broj prijelaznih distributivnih glagola sudjelnici radnje kojih kao trpitelji nose samo semantičko obilježje živoga. Takvi su npr. pobiti (= 'ubiti') (civile), podaviti (kokoši), pogušiti (pčele), poizopijati (uzvanike), 
poklati (stoku), pokrštavati (domorodce), potući (zarobljenike), poubijati (učenike), poudati (kćeri), poudavati (stare cure), poujedati (prolaznike), poženiti (sinove), pomlatiti (ranjenike), posmicati (nepoćudne), posmirivati (nezadovoljne), postrijeljati (prijestupnike), potamaniti (gamad), potrovati (štakore). Nešto je više onih prijelaznih distributivnih glagola sudjelnici radnje kojih kao trpitelji nose samo obilježje neživoga. Takvi su npr. pobiti (= 'zabiti') (stupove), počupati (stabla), poisijecati (komade leda), poodsijecati (grane), poiskidati (mladice), poispaljivati (metke), poispiti (vino), poisprekidati (veze), poispremetati (ladice), poispreturati (ormare), poispreplesti (užad), poisprepletati (konce), poizbijati (zube), poizderati (cipele), poiznadijevati (imena), poizodgrizati (korijenje), polijepiti (plakate), pootkidati (dugmad), pootvarati (boce), poplaćati (račune), porazbacati (papire), porušiti (mostove), posagraditi (nebodere), posazidati (kuće), pozabadati (igle), pozabijati (čavle) itd.

U nekim slučajevima nije moguće od prve razlikovati distributivni glagol od nedistributivnoga. Tako je npr. glagol podavati kad je svršen distributivan, s radnjom koja mu se raspodjeljuje na nežive sudjelnike u ulozi trpitelja (podavao je svima dvojke, smiješne nadimke i sl.), a kad je nesvršen i kad znači 'davati' ili 'pridavati', 'pripisivati', nije distributivan (župnik je imao 13 inkvilina (hižara) od kojih je svaki podavao jednog besplatnog težaka; nije tomu podavao veliku važnost). I glagol podizati distributivan je samo kao svršeni, s radnjom koja mu se raspodjeljuje na nežive i žive sudjelnike u ulozi trpitelja (podizao je sve čunjeve, podanike je podizao kao od šale), a kao nesvršeni nije distributivan (podizao je teret, kuću, kredit itd.). Jednako je tako i glagol porađati distributivan samo kao svršeni, s radnjom koja mu se raspodjeljuje na žive sudjelnike u ulozi trpitelja (porađala je sinove), a kao nesvršeni nije distributivan (djevojčicu je porađala dva sata). Po istom kriteriju glagol poroditi distributivan je samo ako znači 'višekratno roditi' (porodila je kćeri), a ako znači 'jednokratno roditi', nije distributivan (konačno je porodila sina). Budući da distributivnost ovisi o značenjskom konceptu, i glagol porezati može biti distributivan samo onda ako znači 'odrezati' (porezao je suhe grane), a ako znači 'zarezati', nije distributivan (porezao je prst na ruci). Od dvaju homografnih glagola, poiskapati i poiskápati, oba su distributivna; poiskapati nije prijelazan i imenskom mu se riječju u nominativu u funkciji subjekta na semantičkom planu ne izriče vršitelj radnje, nego se izriče objekt koji je njome obuhvaćen (suze su joj poiskapale); poiskápati je prijelazan i imenskom mu se riječju u akuzativu u funkciji direktnog objekta na semantičkom planu izriče trpitelj radnje 
(poiskapali su mrtve, kosti i sl.). Kad glagol pozaticati znači 'zataći', radnja mu se raspodjeljuje na sudjelnike u ulozi trpitelja koji su obilježeni kao neživi (pozaticao je biljke u zemlju, pozaticala je cvjetove u kosu), a kad znači 'zateći', radnja mu se raspodjeljuje na sudjelnike u ulozi trpitelja koji su obilježeni kao živi (pozaticao je lopove na djelu, pozaticala je kolege u sobi) itd.

\section{ZAKLJUČAK}

Nekoliko ovdje izloženih zapažanja o hrvatskim raspodjelnim glagolima ni izdaleka ne iscrpljuje svu problematiku tih glagola. Dosta je otvorenih pitanja ostalo izvan ovoga prikaza, od njihova morfološkog statusa preko aspektnog značenja do leksikografske obrade. Naša je pozornost bila usmjerena na sintaktičko-semantički opis distributivnih glagola. Nakon njihove definicije, pri čemu su razgraničeni od nedistributivnih, pokušali smo ih, na temelju dovoljno reprezentativnoga popisa, razvrstati s obzirom na njihov sintaktički i semantički odnos prema imenskim riječima kojima se uz te glagole u rečenici izriču subjekt i direktni objekt. Na taj su način dobiveni vrlo zanimljivi rezultati. Uz kritički osvrt na opis distributivnih glagola u hrvatskoj gramatičkoj tradiciji, izneseni su i argumenti za prihvaćanje drugačijeg pristupa tim glagolima, pristupa u kojemu je, nadamo se, sintaktičko-semantička slika tih glagola mnogo izoštrenija nego što je bila do sada.

\section{LITERATURA}

Babić, Stjepan. 1986. Tvorba riječi u hrvatskom književnom jeziku. Zagreb: JAZU Globus.

Barić, Eugenija i dr. 1995. Hrvatska gramatika. Zagreb: Školska knjiga.

Grubor, Đuro. 1953. Aspektna značenja. Rad JAZU, knj. 4.

Maretić, Tomo. 1899. Gramatika i stilistika hrvatskoga ili srpskoga književnog jezika.

Zagreb: Stj. Kugli.

Silić, Josip i Pranjković, Ivo. 2005. Gramatika hrvatskoga jezika za gimnazije i visoka učilišta. Zagreb: Školska knjiga.

Dickey, Stephen. 2003. Distributive Verbs in Serbian and Croatian. „Indiana Slavic Studies" 12, 103-115. 


\section{SUMMARY \\ CROATIAN DISTRIBUTIVE VERBS}

Distributive verbs in Croatian form a special group of verbs which distinguishes itself by a specific syntactic feature which is semantically conditioned by their verbal content being distributed to more participants. When more than one participant is denoted, it is not a noun in singular that is mostly used. For that reason the subjects and objects which appear with such distributive verbs can not be expressed by a noun in singular, but only by a substantive in plural, for example Rođaci su mu poumirali, but not Rođak mu je poumirao, Poženio je sinove i poudao kćeri, but not Poženio je sina i poudao kćer, Snopovi su poispadali, but not Snop je poispadao. Collective nouns are an exception to that. Since their singular form expresses the plurality, with distributive verbs they can be in singular as both subjects and objects. The examples are: Narod se porazbolijevao, Lišće je pootpadalo, Rasprodao je imetak, zemlju, djedovinu, obiteljsko srebro, but not Rasprodao je kuću, as it could be Rasprodao je kuće. From the aforementionet, it follows that the distributive verb can serve as a reliable test to identify and split collective nouns from uncollective ones. This test enables us to include in this group many nouns that have not been included in this group until now.

The author critically reviews the description of distributive verbs in grammars and reference books. Special attention is given to the semantic demarcation of distributive verbs from some other verbal groups with which they may, in certain grammatical contexts, be either morphologically identical or may overlap with them.

Key words: distributive verbs, subject, object, syntax 